\title{
Complexity of intravenous iron nanoparticle formulations: implications for bioequivalence evaluation
}

Amy Barton Pai
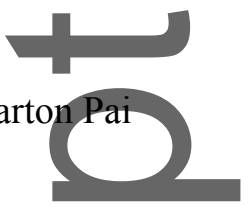

Department of Clinical Pharmacy, University of Michigan College of Pharmacy, Ann Arbor, Michigan

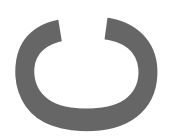

Address for correspondence:

Amy Barton Pai, PharmD, BCPS, FASN, FCCP, FNKF, Associate Professor, Department of Clinical Pharmacy, University of Michigan, College of Pharmacy, 428 Church Street, Ann Arbor, MI 48109. amypai@med.umich.edu

Short title: Bioequivalence challenges with intravenous iron
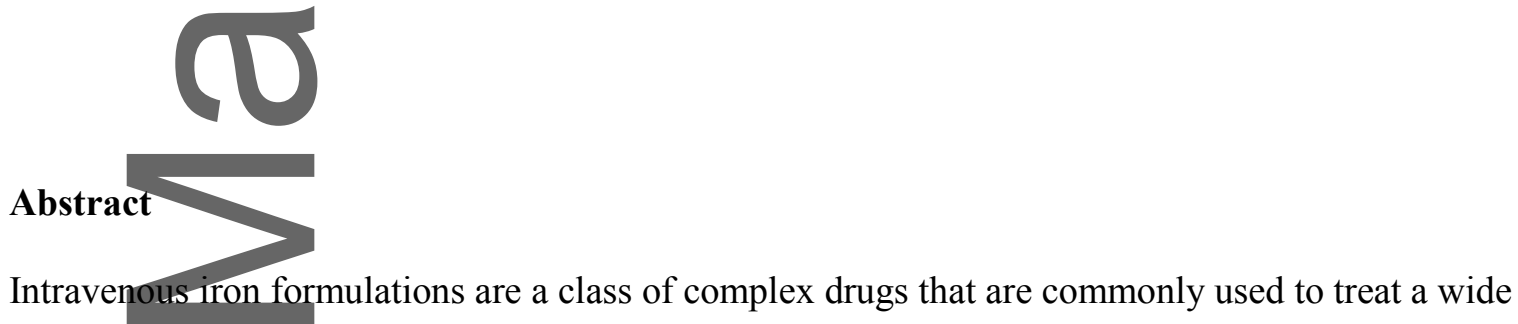
variety of disease states associated with iron deficiency and anemia. Venofer ${ }^{\circledR}$ (iron-sucrose) is one of the most frequently used formulations, with more than $90 \%$ of dialysis patients in the United States receiving this formulation. Emerging data from global markets outside the United States, where many iron-sucrose similars or copies are available, have shown that these formulations may have safety and efficacy profiles that differ from the reference listed drug. This may be attributable to uncharacterized differences in physicochemical characteristics and/or differences in labile iron release. As bioequivalence evaluation guidance evolves, clinicians should be educated on these potential clinical issues before a switch to the generic formulation is made in the clinical setting. Keywords: intravenous iron; nanoparticles; chronic kidney disease, bioequivalence

This is the author manuscript accepted for publication and has undergone full peer review but has not been through the copyediting, typesetting, pagination and proofreading process, which may lead to differences between this version and the Version of Record. Please cite this article as doi: $\underline{10.1111 / \text { nyas. } 13461 .}$

This article is protected by copyright. All rights reserved. 


\section{Introduction}

Intravenous (IV) iron formulations provide a clinical treatment option for chronic kidney disease (CKD) patients when iron supplementation is required but oral administration is not suitable owing to intolerance or lack of efficacy. IV iron use is increasing worldwide, especially in the CKD population. ${ }^{1,2}$ More aggressive IV iron use in the CKD population has been driven by several trials demonstrating adverse safety signals with erythropoiesis-stimulating agents (ESAs). Increased risk of stroke and cardiovascular death and a trend toward higher risk of solid organ cancers were observed in these trials, prompting a product label change by the U.S. Food and Drug Administration (FDA). ${ }^{3-6}$ In 2011, the Centers for Medicare and Medicaid Services instituted a partially capitated payment system (i.e., the bundle) for dialysis services, which included both ESAs and IV iron, which were previously separately billable. ${ }^{7}$ The recombinant ESA therapies are clearly far more expensive than IV iron products, which accelerated a national trend to use larger cumulative doses of IV iron. Doses of ESAs began to decline, and IV iron doses began to rise, even several months in advance of bundle implementation. ${ }^{2}$ More than $70 \%$ of patients receiving chronic hemodialysis receive IV iron, most frequently the reference listed drug (RLD) Venofer ${ }^{\circledR}$ (iron sucrose). ${ }^{8}$ The most common doses administered (19\%) range from 1.2-2.5 g of elemental iron annually; however, a nearly equal proportion of patients (15\%) receive $4.8 \mathrm{~g}$ or more annually. ${ }^{8}$ The Dialysis Outcomes Practice Patterns study reported that mean ferritin increased from 640 to $826 \mathrm{ng} / \mathrm{mL}$ from prebundle to postbundle (January 2012) and remained stable through December 2013. ${ }^{8}$ The percent reported that ferritin $>$ $1200 \mathrm{ng} / \mathrm{mL}$, a biomarker of stored iron, increased from $8.6 \%$ to $18 \%{ }^{9}$

similar (ISS), on the global market. When compared to the reference listed drug (RLD) Venofer, several ISS formulations have been shown in translational models to have significantly more tissue iron deposition, induce greater tissue cytokine expression, and cause endothelial dysfunction. ${ }^{10-12}$

This article is protected by copyright. All rights reserved. 
Here, I evaluate IV iron in the context of its complex formulations and biodistribution and the factors that impart challenges in evaluation of bioequivalence.

\section{Complex chemistry and biodistribution of IV iron formulations create inherent challenges for} bioequivalence

Early IV iron compounds were formulated as inorganic iron-oxyhydroxide complexes. With little relative protection of the inorganic ferric iron, these formulations were highly toxic, with high incidences of severe hypotension. ${ }^{13}$ Current commercially available IV iron formulations consist of an iron-oxyhydroxide core surrounded by carbohydrate shells of various sizes and polysaccharide branch characteristics. ${ }^{13,14}$ The size of commercially available IV iron-carbohydrate complexes range from 5 to $100 \mathrm{~nm}$, and thus meet the definition for nanoparticle formulations. ${ }^{15}$ The manufacture of ironcarbohydrate complex formulations is highly sensitive to $\mathrm{pH}$, temperature, and other conditions in the manufacturing process. This presents significant challenges to reproducible manufacturing, characterization, and safety of generic or similar IV iron product production.

Iron oxide nanoparticles with magnetic particle cores are well-established magnetic resonance imaging (MRI) agents and have been used safely; however, different carbohydrate shell structures determine the relative uptake by endothelial and lymphatic cells as well as the by the reticuloendothelial system. ${ }^{15}$ The clinical use of iron-carbohydrate nanoparticle formulations has not been well studied with regard to potential long-term toxicity beyond immediate labile iron appearance and immunogenicity. ${ }^{15}$ Because commercially available IV iron formulations used in CKD meet the criteria for nanoparticles, their pharmacodynamic profile with regard to direct cell uptake and subsequent physiological effects needs to be better characterized for both RLDs and current and future generic formulations. ${ }^{16,17}$

Pharmacokinetic evaluation of IV iron complexes is challenging, unless the compound can be directly measured (ferromagnetic) or is manufactured with a radiolabeled form of iron $\left({ }^{59} \mathrm{Fe}\right)$ to distinguish the IV iron formulation from endogenous serum iron. While not well appreciated by clinicians, IV iron formulations exhibit zero-order or capacity-limited metabolism by the

This article is protected by copyright. All rights reserved. 
reticuloendothelial system. This results in longer residence time in plasma with higher administered doses, especially with higher-molecular-weight formulations. ${ }^{18}$ This has potentially important implications regarding toxicity profiles, as doses administered beyond the reticuloendothelial system capacity linit will remain circulating in plasma for long periods of time until the concentration falls below the capacity limit, at which time the pharmacokinetic profile will become linear or concentration independent. When the RLD Feraheme ${ }^{\circledR}$ (ferumoxytol) was administered as two 510mg IV doses $24 \mathrm{~h}$ apart to healthy subjects, the metabolism did not appear to become linear until approximately 96 h after the first dose. ${ }^{18}$ Hillman et al. showed that radiolabeled iron-dextran exhibited capacity-limited metabolism at $500 \mathrm{mg}$, whereas the 250-mg dose appeared to have a linear pharmacokinetic profile. ${ }^{19}$ Ultimately, the complexity of IV iron-carbohydrate complex nanoparticle formulations has important implications with regard to both efficacy and safety in CKD. These agents have not been well studied with regard to comparative biodistribution, metabolic fate, or potential extracellular and intracellular toxicity profiles, and further evaluation of these agents is urgently needed, as long-term clinical use is widespread.

Current regulatory guidance provides some recommendations for physicochemical characterization and pharmacokinetics of these agents. This is especially relevant for abbreviated new drug applications for generic formulations, which necessitate independent clinical and translational studies to elucidate comparative product characteristics. ${ }^{20}$ Even slight changes (temperature, $\mathrm{pH}$, polymer content) in the co-precipitation reaction to synthesize iron-carbohydrate nanoparticles can alter the properties of the final product, presenting challenges to reproducible manufacturing of IV iron formulations to be considered for generic approval. ${ }^{21,22}$ These formulations have been referred to as similars, as exact copies cannot be formulated. ${ }^{11,21}$ Although it has been shown that, if the iron complex is thermodynamically stable, complexes of similar molecular weight can be synthesized using multiple different manufacturing procedures, this may or may not translate to similar disposition in vivo. ${ }^{23,24}$ Simple fold dilutions in polymer content during iron oxide-dextran co-precipitation have yielded particles with similar hydrodynamic diameters determined by dynamic light scattering; however, the cellular iron uptake and cell viability are markedly different among the particles. ${ }^{22}$ 
Several ISSs available outside the United States have been shown to not meet United States Pharmacopeia (USP) Reference Standards. ${ }^{10,11}$ Differences in molecular weight, titratable alkalinity, and kinetics of degradation have also been shown between lots of the same generic formulation. ${ }^{11,24}$ Toblli et al characterized the physicochemical characteristics of the RLD Venofer and compared these to several of the compounds available and in clinical use in Europe and Asia. ${ }^{11,25}$ Notably, only one generic product in these comparative analyses complied with USP criteria. Differences in one or more of the criteria- $-\mathrm{pH}$, titratable alkalinity, and turbidity point — were observed in all generic products evaluated. Four of the seven products (57\%) evaluated in one study ${ }^{11}$ had markedly higher molecular weights measured by gel-permeation chromatography. In animal studies using $40-\mathrm{mg} / \mathrm{kg}$ single IV doses, generic iron products have been shown to be associated with higher tissue concentrations of proinflammatory cytokines, higher intracellular antioxidant enzyme activity, adverse effects on the basic metabolic profiles (elevated liver function tests), and kidney dysfunction (elevated serum creatinine and proteinuria). ${ }^{10,11,25-27}$ It has been hypothesized that labile iron is principally involved with these observed deleterious effects by generating reactive oxygen species via the Fenton-Haber-Weiss reaction. In a systematic series of experiments, in vitro labile iron release profiles were evaluated for six IV iron formulations. ${ }^{28}$ The formulations studied included the only approved generic IV iron in the United States (sodium ferric gluconate complex) and the RLD Ferrlecit ${ }^{\circ}$. Labile iron release in both saline and rat serum matrices was higher for the RLD versus the generic SFGC, indicative of some formulation variability. To date, no published studies comparing RLDs with generic IV iron formulations have evaluated labile iron release profiles in human subjeets. ${ }^{10,1122-27}$ Because generic iron-carbohydrate complex formulations may differ with regard to molecular weight, carbohydrate shell chemistry, shell and particle diameter, and osmolality $^{13,14}$ these agents require additional considerations for bioequivalence testing. ${ }^{21}$

\section{Adverse safety signals from in vitro, animal, and human studies: RLDs and iron-sucrose}

\section{similars}

The hypothesis for the pathogenesis of acute oxidative stress induced by IV iron formulations is the

This article is protected by copyright. All rights reserved. 
release of labile iron from the iron-carbohydrate structure resulting in transient concentrations of labile plasma iron and induction of the Fenton chemistry and the Haber-Weiss reaction, promoting formation of highly reactive free radicals, such as the hydroxyl radical. ${ }^{29}$ Labile plasma iron is the oxidative reactive fraction of non-transferrin-bound iron, iron that is not tightly bound transferrin. Among available RLD IV iron formulations, products with smaller carbohydrate shells are more labile and more likely to release labile iron directly into the plasma (i.e., before metabolism by RES) (Table 1). ${ }^{30,31}$ The proposed biologic targets of labile iron-induced oxidative stress include nearly all systemic celhular components, including endothelial cells, myocardium, and liver, as well as lowdensity-lipoprotein and other plasma proteins. Because of the extremely short half-lives of free radicals and the rapidity of the ensuing oxidative stress reactions produced by labile iron appearance, in vivo evaluation of this toxicity profile can only reasonably be accomplished by using biomarkers as surrogates. Recently, a systematic review of widely used biomarkers was conducted to assess oxidative stress in CKD. The authors applied scores for commonly used biomarkers for relationships to other biomarkers and clinical indicators, reliability, and characterization in the CKD literature. ${ }^{32}$<smiles>[CH]1C=C1</smiles>
Many of the identified "robust" biomarkers have been evaluated in the context of potential IV iron toxicity in CKD (malondialdehyde, protein carbonyl, and F2-isoprostane); however, it should be noted that none of the identified biomarkers have specificity for iron-induced oxidative stress. ${ }^{33,34} \mathrm{An}$ additional concern regarding appearance of labile plasma iron is the potential for easily accessible iron to impair innate immunity and augment bacterial growth, increasing the risk of infection. ${ }^{35}$

IV iron formulations have clearly been shown to induce oxidative stress, inflammation, and cellulartoxicity in cell culture models, animal models, and acutely in human subjects. ${ }^{10-12,30,34}$ Differentialtoxicity profiles have been observed among the available IV iron products in vitro, with more labile compounds inducing more toxicity than compounds with larger carbohydrate shells that exhibit better stability. ${ }^{35,36}$ In animal models, similar observations have been reported with administration of IV iron compounds inducing labile iron appearance, pro-oxidant cell signaling, tissue inflammation, cellular iron deposition, and cytotoxicity. ${ }^{10,32,37,38}$ IV iron has also been associated with immune dysfunction and increased Gram-positive bacteria growth in vitro. ${ }^{11,36,39}$ In 
some studies, a similar rank order for toxicity (labile products $>$ stable products) has been demonstrated; ${ }^{35}$ however, other studies have shown greater cellular iron staining and tissue inflammation with higher-molecular-weight products. ${ }^{11}$ In similar rat models, increased tissue oxidative stress has been observed with several ISS (i.e., generic) products compared with the branded product $^{10}$ A caveat to interpretation of these in vivo animal model data is the wide variation in doses administered in the experiments $(1.4 \mathrm{mg} / \mathrm{kg}$ to $500 \mathrm{mg} / \mathrm{kg}){ }^{10,31,37}$ While the dose in the rat should be higher on the basis of allometric scaling, the optimal dose to model human IV iron toxicity has not been determined

Although the biological plausibility and available in vitro and animal model data are generally compelling, controversy remains regarding whether iron-induced oxidative stress manifests long-term toxicity, such as cardiovascular disease and infection, in CKD patients. The complex biochemical milieu in CKD, in tandem with the multiple inciting factors for oxidative stress and inflammation, complicates investigation of potential IV iron safety concerns.-Epidemiologic analyses conducted with dialysis patient data in the late 1990s demonstrated positive correlations between the number of IV iron vials billed and mortality. ${ }^{40}$ Given that the impact of iron-induced oxidative stress on cardiovascular disease likely takes extended periods of time, immediate correlation of iron dose to cardiovascular events is not likely possible. In later analyses with newer data, application of more sophisticated statistical analyses with incorporation of lag times to adjust for time-varying confounders found that the relationship between IV iron and cardiovascular outcomes was not statistically significant. ${ }^{41}$ A recent analysis evaluated short-term cardiovascular risk associated with IV iron dosing practices (bolus vs. maintenance and high dose vs. low dose). ${ }^{42}$ Large-dose strategies (bolus and high dose) were not associated with increased risk of cardiovascular death, hospitalization for myocardial infarction, hospitalization for stroke, or any composite/combination of any of these three. ${ }^{42}$ Evaluating the relationship between iron and infection risk could be more easily evaluable, given that the presumed risk of infection would

This article is protected by copyright. All rights reserved. 
likely be in close proximity to the dose administered when labile iron is presumably present. In a small retrospective study, 132 dialysis patients receiving their first course of IV iron were followed for 1 year after therapy initiation for time to first bacteremia episode. ${ }^{43}$ Patients with transferrin saturation values $\geq 20 \%$ and ferritin $\geq 100$ were defined as iron replete, and this group had 2.5-fold higher risk of bacteremia compared with patients with functional iron deficiency and those who were iron deficient. ${ }^{43}$ These data may suggest that iron availability is increased when additional iron is administered to these iron-replete patients, promoting bacterial growth and subsequent bloodstream infections. More recently, a large epidemiologic study examined the risk of infection-related hospitalization with bolus versus maintenance or high versus low IV iron-dosing patterns. ${ }^{44}$ Bolus dosing of IV iron was associated with a higher risk of infection-related hospitalization (25 additional events per 1000 patient-years) and increased risk of mortality. Differences in infection rates between iron formulations have been less clear. In two studies evaluating U.S. Renal Data System data, short-term-infection risk in hemodialysis patients with sodium ferric gluconate was marginally lower than iron sucrose. ${ }^{45}$ In contrast, longer-term infection risk was modestly lower in iron-sucrose-treated hemodialysis patients. ${ }^{46}$ Prospective studies are needed to elucidate whether risk and predictors of infection differ among formulations.

In interventional clinical trials and observational reports, when compared to the RLD, different formulations and lots of ISS have been associated with intracellular reactive oxygen species generation, increases in biomarkers of endothelial dysfunction, and adverse drug events, including hypotension and phlebitis. ${ }^{12,26,47,48}$ Labile iron release in the immediate postadministration period (directly from the formulation) from RLD iron-carbohydrate complexes has been shown to induce oxidativestress, cytokine activation, and endothelial dysfunction. ${ }^{12,30,49}$ Therefore, the biologic plausibility strongly implies that differences in labile iron release are fundamentally responsible for the higher rates of adverse drug events reported with generic iron-sucrose formulations. Table 2 summarizes published studies evaluating RLDs and ISS products across the translational research

This article is protected by copyright. All rights reserved. 
spectrum.

\section{Formulation-based labile iron release is a viable and pragmatic parameter for enhancing $\mathrm{BE}$ evaluation of generic IV iron products}

As discussed, the biologic plausibility of labile iron being a fundamental cause of adverse drug events (excluding immunogenetic reactions) related to IV iron formulations is strong and supported by translational research evaluating several of the RLD products. ${ }^{24,48}$ The higher incidence of hypotension reported with some generic formulations, including different lots of the same formulation, is likely attributable to formulation-based free iron release..$^{24,48}$ Thus, labile iron measurement is a both a relevant and practical candidate to further evaluate BE of generic IV iron formulations. ${ }^{29,49,50}$ Assessment of labile iron-release profiles extends data provided by physicochemical characterization (PCC) to better understand how the disposition of generic formulation compares to the RLD. As mentioned previously, despite evidence of similar PCC, these complex formulations may behave differently in in vivo systems. ${ }^{51}$ This underscores the need for a multipronged approach in evaluation of BE among complex drug formulations. Animal studies evaluating generic iron sucrose formulations have evaluated serum iron concentrations and transferrin saturation (TSAT) and found values to be higher in animals receiving the generic formulations versus the RLD. ${ }^{10,11,25-27}$ However, TSAT is not a direct measurement of the reactive labile iron species and does not adequately represent the potential for deleterious redox reactions. Although TSAT values greater than $100 \%$ strongly infer the presence of labile iron, we and others have shown that labile iron is present at TSAT values less than $100 \%$, limiting the utility of this parameter. ${ }^{30,52}$ An optimal approach for BE for generic IV iron formulations would be development of an in vitro to in vivo correlation (IVIVC) model. A validated IVIVC model would allow in vitro labile iron-release kinetics under physiologically relevant conditions to support BE evaluation in addition to rigorous PCC with standards. ${ }^{50,53}$ Several assays have been developed and validated to measure labile plasma iron, mainly employing redox-active or chelatable methodologies; however, many of these assays are not viable for in vitro determination of labile iron release from the formulation. ${ }^{28,29} \mathrm{Jahn}$ et al. used the Ferrozine ${ }^{\circledR}$ assay to determine iron 
release among six available IV iron formulations in vitro incubated in human serum. ${ }^{14}$ Lowermolecular-weight formulations and higher concentrations representing clinically relevant doses were associated with higher concentrations of iron release. However, it should be noted that this assay measures non-transferrin-bound iron (labile reactive iron plus iron weakly bound to other plasma proteins) and may overestimate formulation-based labile iron release.

The difficulties in evaluating non-biologic complex drugs, such as IV iron formulations, is appreciated by scientists and regulatory agencies. ${ }^{53,54}$ However, most clinicians who ase these formulations across a wide spectrum of acute and chronic disease states are not aware of their complicated pharmacokinetic and pharmacodynamic profiles, nor do they appreciate the challenges in BE evaluation of generic formulations. A survey administered to 140 pharmacists in France and Spain was designed to provide insight into the current decision-making process for pharmacists regarding IV iron products in the hospital. ${ }^{55}$ Substitution of RLD iron-sucrose for an ISS ranged from $38-47 \%$. However, only $19 \%$ and $7 \%$ of pharmacists in France and Spain, respectively, thought there were relevant differences between RLD and ISS formulations.

Taken collectively, there is a need for comprehensive clinical and translation investigations of IV iron formulations to mechanistically evaluate and understand the biodistribution, safety, and toxicity profiles of these agents. Such studies would be useful in moving the needle forward on BE evaluation to ensure safe and effective generic IV iron products.

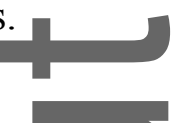

Acknowledgments

Competing interests

The author declares no competing interests.

\section{References}

This article is protected by copyright. All rights reserved. 
1. Hirth, RA, MN Turenne, JR Wheeler et al. 2013. The initial impact of Medicare's new prospective payment system for kidney dialysis. Am. J. Kidney Dis. 62:662-669

2. Chärytan $\overline{\mathrm{DM}}, \mathrm{AB}$ Pai, CT Chan et al. 2015. Considerations and challenges in defining optimal iron utilization in hemodialysis. J. Am. Soc. of Nephrol. 26(6):1238-1247.

3. Besarab, A, WK Bolton, JK Browne et al. 1998. The effects of normal as compared with low hematocrit values in patients with cardiac disease who are receiving hemodialysis and epoetin. N Engl .J Med, 339: 584-590

4. Pfeffer, MA, EA Burdmann, CY Chen, et al. 2009. A trial of darbepoetin alfa in type 2 diabetes and chronic kidney disease. N. Engl. J. Med, 361: 2019-2032

5. Singh, AK, L Szczech, KL Tang et al. 2006. Correction of anemia with epoetin alfa in chronic kidney disease. N. Engl. J. Med, 355: 2085-2098

6. Drueke, TB, F Locatelli, N Clyne et al. 2006. Normalization of hemoglobin level in patients with chronic kidney disease and anemia. N. Engl. J. Med. 355: 2071-2084

7. Medicare Program; end-stage renal disease prospective payment system. Final Rule. In: SERVICES, C. F. M. M. (Ed.), Fed Register, 2010 pp 49029-49214

8. Bailie GR, M Larkina, DA Goodkin et al. 2015. Data from the Dialysis Outcomes and Practice Patterns Study validate an association between high intravenous iron doses and mortality Kidney Int. 87(1):162-8.

9. DOPPS Practice Monitor. Arbor Research Collaborative for Health, June 2014

10. Toblli JE, G Cao, L Oliveri et al. 2011. Assessment of the extent of oxidative stress induced by intravenous ferumoxytol, ferric carboxymaltose, iron sucrose and iron dextran in a nonclinical model. Arzneimittelforschung. 61(7),399-410

11. Toblli JE, G Cao, L Oliveri et al. 2012. Comparison of oxidative stress and inflammation induced by different intravenous iron sucrose similar preparations in a rat model. Inflamm Allergy Drug Targets 11(1),66-78.

12. Kuo KL, SC Hung, TS Lee, et al. 2014. Iron sucrose accelerates early atherogenesis by increasing superoxide production and upregulating adhesion molecules in CKD. $J$ Am Soc Nephrol. 2014 25(11):2596-606.

13. Danielson BG. 2004. Structure, chemistry, and pharmacokinetics of intravenous iron agents. J.Am. Soc. Nephrol. 15 Suppl 2,S93-8.

14. Jahn MR, HS Andreasen, S Futterer et al. 2011. A comparative study of the physicochemical properties of iron isomaltoside 1000 (Monofer ${ }^{\circledR}$ ), a new intravenous iron preparation and its clinical implications. European Journal of Pharmaceutics and Biopharmaceutics. 78, 480491.

This article is protected by copyright. All rights reserved. 
15. Duncan R, R Gaspar. 2011 Nanomedicine(s) under the microscope. Mol Pharm. 8(6),210141

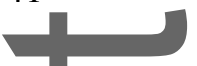

16. Stein J, A Dignass, KU Chow. 2012. Clinical case reports raise doubts about the therapeutic equivalence of an iron sucrose similar preparation compared with iron sucrose originator. Curr Med Res Opin. 28(2),241-3.

17. Wu X, Tan Y, Mao H, Zhang M. Toxic effects of iron oxide nanoparticles on human umbilical vein endothelial cells. Int J Nanomedicine. 2010 Aug 9;5,385-99.

18. Pai AB, Nielsen JC, Kausz A, Miller P, Owen JS. Plasma pharmacokinetics of two consecutive doses of ferumoxytol in healthy subjects. Clin Pharmacol Ther 2010 Aug;88(2):237-42.

19. Henderson PA, RS Hillman. 1969 Characteristics of iron dextran utilization in man. Blood. 34(3),357-75.

20.

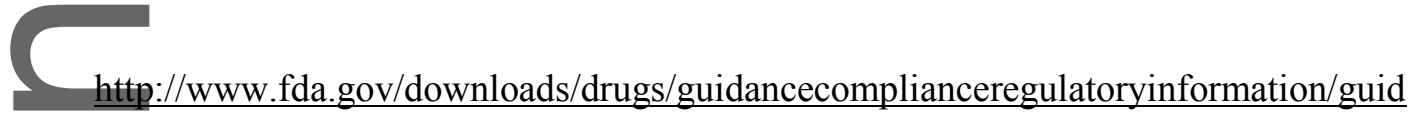
ances/ucm297630.pdf accessed 12-June-2017

21. European Medicines Agency. Reflection paper on the data requirements for intravenous ironbased nano-colloidal products developed with reference to an innovator medicinal product. Available from: http:/Www.ema.europa.eu/docs/en_GB/document_library/Scientific_guideline/2015/03/WC5 00184922.pdf. 2015. Accessed 12-June-2017

22. Barrow M, A Taylor, J García Carrión J, et al. 2016 Co-precipitation of DEAE-dextran coated SPIONs: how synthesis conditions affect particle properties, stem cell labelling and MR eontrast. Contrast Media Mol Imaging. 1(5):362-370

23. Yang Y, RB Shah, PJ Faustino et al. 2010 Thermodynamic stability assessment of a colloidal iron drug product: sodium ferric gluconate. J Pharm Sci. 99:142-53.

24. Lee ES, Park BR, Kim JS, Choi GY, Lee JJ, Lee IS. Comparison of adverse event profile of intravenous iron sucrose and iron sucrose similar in postpartum and gynecologic operative patients. Curr Med Res Opin. 2013 Feb;29(2):141-7

25. Toblli JE, G. Cao, M. Angerosa. 2015 The Induction of Oxidative/Nitrosative Stress, Inflammation, and Apoptosis by a Ferric Carboxymaltose Copy Compared to Iron Sucrose in a Non-Clinical Model. J Clin Diagn Res. 9(12):FF08-12

26. Toblli JE, G Cao, L Olieveri et al. 2009 Differences between original intravenous iron sucrose and iron sucrose similar preparations. Arzneimittelforschung. 59(4):176-90.

This article is protected by copyright. All rights reserved. 
27. Toblli JE, Cao G, Angerosa M. 2015 Nitrosative stress and apoptosis in non-anemic healthy rats induced by intravenous iron sucrose similars versus iron sucrose originator. Biometals.

28(2): 279

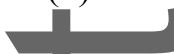

28. Pai A, Meyer D, Bales B, et al. 2017 Performance of redox active and chelatable iron assays to determine labile iron release from intravenous iron formulations. Clinical and Translational Science. 10(3):194-200.

29. Cabantchik ZI. 2014 Labile iron in cells and body fluids: physiology, pathology, and pharmacology. Front Pharmacol 13;5,45

30. Pai AB, AV Boyd, CR McQuade et al. 2007 Comparison of oxidative stress markers after intrayenous administration of iron dextran, sodium ferric gluconate, and sucrose in patients undergoing hemodialysis. Pharmacotherapy. 27(3),343-350

31. Balakrishnan VS, M Rao, AT Kausz et al. 2009 Physicochemical properties of ferumoxytol, a new intravenous iron preparation. Eur J Clin Invest. 39(6), 489-496

32. Tucker PS, VJ Dalbo, T Han et al. 2013 Clinical and research markers of oxidative stress in chronic kidney disease. Biomarkers. 18(2),103-15

33. Fishbane S, A Mathew, ND Vaziri. 2014 Iron toxicity: relevance for dialysis patients.

Nephrol Dial Transplant. 29(2),255-9

34. Johnson AC, Becker K, Zager RA. 2010 Parenteral iron formulations differentially affect MCP-1, HO-1, and NGAL gene expression and renal responses to injury. Am J Physiol Renal Physiol. 299(2), F426-35

35. Gupta A, J Zhuo, J Zha et al. 2010 Effect of different intravenous iron preparations on lymphocyte intracellular reactive oxygen species generation and subpopulation survival. $B M C$ Nephrol. 2010 17;11,16

36. Zager RA, Johnson AC, Hanson SY et al. 2002 Parenteral iron formulations: a comparative toxicologic analysis and mechanisms of cell injury. Am J Kidney Dis 40,90-103.

37. Lim CS, Vaziri ND. 2004 The effects of iron dextran on the oxidative stress in cardiovascular tissues of rats with chronic renal failure. Kidney Int 2004 65(5),1802-9.

38. Parkkinen J, L von Bonsdorff, S Peltonen et al. 2000 Catalytically active iron and bacterial growth in serum of haemodialysis patients after i.v. iron-saccharate administration. Nephrol Dial Transplant. 15(11),1827-34.

39. Barton Pai-A, MP Pai, J Depczynski et al. 2006 Non-transferrin-bound iron is associated with enhanced Staphylococcus aureus growth in hemodialysis patients receiving intravenous iron sucrose. Am J Nephrol 26(3),304-9

This article is protected by copyright. All rights reserved. 
40. Collins AJ, J Ebben, JZ Ma et al. 1998 intravenous iron dosing patterns and mortality [Abstract]. J Am Soc Nephrol. 9:205A

41. Feldman HI, M Joffe, B Robinson et al. 2004 Administration of parenteral iron and mortality among hemodialysis patients. J Am Soc Nephrol. 15(6),1623-32.

42. Kshirsagar AV, Freburger JK, Ellis AR et al. 2013 intravenous iron supplementation practices and short-term risk of cardiovascular events in hemodialysis patients. PLoS One. $1 ; 8(11)$

43. Teehan GS, D Bahdouch, R Ruthazer et al. 2004 Iron storage indices: novel predictors of bacteremia in hemodialysis patients initiating intravenous iron therapy. Clin Infect Dis $15 ; 38(8), 1090-4$

44. Brookhart MA, JK Freburger, AR Ellis et al. 2013 Infection risk with bolus versus maintenance iron supplementation in hemodialysis patients. $J$ Am Soc Nephrol. 24(7),1151-8.

45. Winkelmayer WC, BA Goldstein, AA Mitani, et al. 2017 Safety of intravenous iron in hemodialysis: Longer-term comparisons of iron sucrose versus sodium ferric gluconate complex. Am. J. of Kidney Dis. 69(6):771-779

46. Brookhart MA, JK Freburger, AR Ellis et al. 2016 Comparative short-term safety of sodium ferric gluconate versus iron sucrose in hemodialysis patients. Am. J. of Kidney Dis. 67(1):119.

47. Martin-Malo A, Merino A, Carracedo J et al. 2012 Effects of intravenous iron on mononuclear cells during the haemodialysis session. Nephrol Dial Transplant. 27(6):2465-71

48. Stein J, Dignass A, Chow KU. 2012 Clinical case reports raise doubts about the therapeutic equivalence of an iron sucrose similar preparation compared with iron sucrose originator. Curr Med Res Opin. 28(2):241-3.

49. Pai AB, McQuade C, Olp J et al. 2011 Non-transferrin bound iron (NTBI), cytokine activation and intracellular reactive oxygen species generation in hemodialysis (HD) patients receiving iron dextran (ID) or iron sucrose (IS). Biometals. 24:603-13.

50. Zheng N, DD Sun, P Zou et al. 2017 Scientific and regulatory considerations for generic complex drug products containing nanomaterials. The AAPS Journal. 19(3):619-631

51. Elford P, JBouchard, L Jaillet et al. 2013 Biodistribution and predictive hepatic gene expression of intravenous iron sucrose. J Pharmacol Toxicol Methods. 68(3):374-83.

52. Slotki I, Cabantchik ZI. 2015 The labile side of iron supplementation in CKD. J Am Soc Nephrol. 26(11):2612-9

53. Zhang X, N Zheng, RA Lionberger. et al. 2013 Innovative approaches for demonstration of bioequivalence: The US FDA perspective. Therapeutic delivery. 4(6):725-740.

This article is protected by copyright. All rights reserved. 
54. Macdougall IC, Bircher AJ, Eckardt K, et al. 2016 Iron management in chronic kidney disease: Conclusions from a "Kidney disease: Improving global outcomes" (KDIGO) controversies conference. Kidney Int. 89(1):28-39

55. Knoeff, J, Flumann, B, Muhlebach, S. 2017 Medication practice in hospitals: are nanosimilars evaluated and substituted correctly. Eur J Hosp Pharm. 0:1-6

56. Spicher K, S Brendler-Schwaab, Schlösser C, et al. 2015 Differences in tissue distribution of iron from various clinically used intravenous iron complexes in fetal avian heart and liver. Regulatory toxicology and pharmacology. 73(1):65-72.

57. Rottembourg J, A Kadri, E Leonard et al. 2011 Do two intravenous iron sucrose preparations have the same efficacy? Nephrol Dial Transplant. 26(10):3262-7

58. Agüera ML, A Martin-Malo, MA Alvarez-Lara et al. 2015 Efficiency of original versus generic intravenous iron formulations in patients on haemodialysis. $\underline{P L O S}$ One. 31;10(8): 0135967.

Table 1. Comparison of physicochemical characteristics and pharmacokinetics of reference listed drug IV iron formulations

\begin{tabular}{|l|l|l|l|l|l|}
\hline PROPERTIES & Feraheme® & Injectafer ${ }^{\circledR}$ & InFed ${ }^{\circledR}$ & Venofer ${ }^{\circledR}$ & Ferrlecit ${ }^{\circledR}$ \\
\hline MW (Da) & 731,000 & 150,000 & 410,000 & 252,000 & 200,000 \\
\hline $\begin{array}{l}\text { Carbohydrate } \\
\text { shell }\end{array}$ & $\begin{array}{l}\text { Polyglucose } \\
\text { sorbitol } \\
\text { carboxymethylether }\end{array}$ & Carboxymaltose & $\begin{array}{l}\text { Detran } \\
\text { polysaccharide }\end{array}$ & Sucrose & $\begin{array}{l}\text { Gluconate, } \\
\text { loosely } \\
\text { associated } \\
\text { sucrose }\end{array}$ \\
\hline $\begin{array}{l}\text { Median shell/ } \\
\text { particle } \\
\text { diameter (nm) }\end{array}$ & 26.3 & 23.1 & 12.2 & 8.3 & 8.6 \\
\hline $\begin{array}{l}\text { Relative labile } \\
\text { Fe release }\end{array}$ & + & + & ++ & +++ & +++ \\
\hline $\begin{array}{l}\text { Relative } \\
\text { stability of } \\
\text { elemental Fe } \\
\text { within the } \\
\text { CHO Shell }\end{array}$ & High & High & High & Medium & Low \\
\hline $\begin{array}{l}\text { Relative } \\
\text { osmolalities }\end{array}$ & Isotonic & Isotonic & Isotonic & Hypertonic & Hypertonic \\
\hline $\begin{array}{l}\text { Administratio } \\
\text { n (IV push) }\end{array}$ & $30 \mathrm{mg} / \mathrm{sec}$ & Bolus push & $\begin{array}{l}50 \mathrm{mg}(1 \mathrm{~mL}) / \\
\text { min }\end{array}$ & $\begin{array}{l}\sim 20 \\
\text { mg/min }\end{array}$ & $\begin{array}{l}12.5 \\
\text { mg/min }\end{array}$ \\
\hline
\end{tabular}

This article is protected by copyright. All rights reserved. 


\begin{tabular}{|l|l|l|l|l|l|}
\hline rates & & & & & \\
\hline Half-life (hrs) & $\sim 15$ & $7-12$ & $5-20$ & 6 & $\sim 1$ \\
\hline
\end{tabular}

IV, intravenous; CHO, carbohydrate.
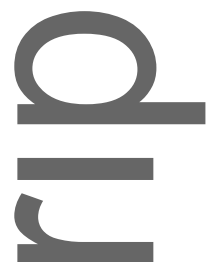

Table 2. Summary of in vitro, animal and human subject studies comparing iron-sucrose similars (ISSs) to the RLD Venofer

\begin{tabular}{|c|c|c|c|}
\hline Author & Formulations studied & Study design & Key findings \\
\hline \multicolumn{4}{|l|}{ In vitro } \\
\hline Kuo et al. & $\begin{array}{l}\text { ISS (Nan-Kuang } \\
\text { Pharmaceuticals) vs. } \\
\text { control }\end{array}$ & $\begin{array}{l}\text { Human aortic } \\
\text { endothelial cells } \\
\text { (HAECs) and } \\
\text { monocytes (U937) } \\
\text { incubated with ISS } 40- \\
160 \mu \mathrm{g} / \mathrm{mL} \text { for } 4 \text { hours. }\end{array}$ & $\begin{array}{l}\text { Time-dependent } \\
\text { intracellular iron } \\
\text { uptake, ROS } \\
\text { generation, NADPH } \\
\text { oxidase (NOX) } \\
\text { activity, VCAM-1, } \\
\text { ICAM-1, increased } \\
\text { NF-кB in HAECS, and } \\
\text { endothelial-monocyte } \\
\text { adhesion highest in } \\
\text { ISS-treated cells }\end{array}$ \\
\hline \multicolumn{4}{|c|}{ In vivo animal } \\
\hline Toblli et al. & $\begin{array}{l}\text { Venofer, ISS test } 1,{ }^{a} \text { ISS } \\
\text { test } 2,{ }^{a} \text { control }\end{array}$ & $\begin{array}{l}\text { Single } 40 \mathrm{mg} / \mathrm{kg} \text { IV } \\
\text { injection in rats. Serum } \\
\text { and tissue samples } \\
\text { collected at } 24 \mathrm{~h} \text {, and } 7 \\
\text { and } 28 \text { days. }\end{array}$ & $\begin{array}{l}\text { Higher tissue iron } \\
\text { deposition, antioxidant } \\
\text { enzyme, and cytokine } \\
\text { generation with both } \\
\text { ISS formulations vs. } \\
\text { RLD and control } \\
\text { observed at } 24 \mathrm{~h} \text { and } \\
\text { day } 7 \text {. No difference at } \\
\text { day } 28 .\end{array}$ \\
\hline Toblli eta & $\begin{array}{l}\text { Venofer, six ISS } \\
\text { formulations sourced } \\
\text { from Pakistan, India, and } \\
\text { Taiwan }\end{array}$ & $\begin{array}{l}\text { Rats randomly } \\
\text { allocated to receive } 40 \\
\mathrm{mg} / \mathrm{kg} \text { IV of an IV iron } \\
\text { formulation or saline at } \\
\text { days } 0,7,14,21 \text {, and } \\
28 \text {. Serum collected at } \\
\text { day } 1,8,15,22 \text {, and } \\
29 . \text { Tissue samples } \\
\text { collected at day } 29 .\end{array}$ & $\begin{array}{l}\text { Higher serum iron, } \\
\text { TSAT observed at days } \\
1,8 \text {, and } 29 \text { with all } \\
\text { ISS formulations vs. } \\
\text { RLD and control. } \\
\text { Higher tissue iron } \\
\text { deposition observed } \\
\text { with ISS }^{b} \text { vs. RLD and } \\
\text { control; higher tissue } \\
\text { cytokines (TNF- } \alpha \text {, IL- } \\
\text { 6) with ISS }\end{array}$ \\
\hline
\end{tabular}

This article is protected by copyright. All rights reserved. 


\begin{tabular}{|c|c|c|c|}
\hline & & & formulations \\
\hline Kuo et al. ${ }^{12}$ & $\begin{array}{l}\text { ISS (Nan-Kuang } \\
\text { Pharmaceuticals) vs. } \\
\text { control }\end{array}$ & $\begin{array}{l}\text { Mice (C57BL/6) mice } \\
\text { were established in } \\
\text { four groups: sham with } \\
\text { saline, sham with ISS, } \\
\text { uninephrectomy (SNx) } \\
\text { with saline, and SNx } \\
\text { with iron to evaluate } \\
\text { vascular adhesion. A } \\
\text { second group of ApoE }{ }^{-} \\
{ }^{-} \text {mice was established } \\
\text { in the same four groups } \\
\text { to evaluate } \\
\text { atherogenesis. Doses of } \\
\text { ISS were administered } \\
\text { IP at } 2 \text { mg/ } 25 \text { g body } \\
\text { weight for } 5 \text { days. }\end{array}$ & $\begin{array}{l}\text { SNx wild-type mice } \\
\text { treated with iron had } \\
\text { the highest amount of } \\
\text { leukocyte adherence to } \\
\text { aortic endothelium } \\
\text { compared to sham } \pm \\
\text { iron. SNx not treated } \\
\text { with iron had higher } \\
\text { amounts of leukocyte } \\
\text { adherence vs. sham } \pm \\
\text { iron. ROS were highest } \\
\text { in SNx + iron mice, as } \\
\text { was VCAM-1 and } \\
\text { ICAM-1 expression in } \\
\text { aortic tissue. ROS } \\
\text { generation appeared to } \\
\text { be mediated by NOX, } \\
\text { confirmed by p22 } \\
\text { expression in the aortic } \\
\text { endothelium as well as } \\
\text { the medial layer }\end{array}$ \\
\hline Toblli et al & $\begin{array}{l}\text { Eight ISS sourced from } \\
\text { Europe and Asia vs. } \\
\text { three different lots of } \\
\text { Venofer and control }\end{array}$ & $\begin{array}{l}\text { Rats were administered } \\
40 \mathrm{mg} / \mathrm{kg} \text { of Venofer or } \\
\text { one of eight ISSs } \\
\text { adjusted for weekly } \\
\text { body weight and } \\
\text { diluted in saline to a } \\
\text { final volume of } 1 \mathrm{~mL} \text { at } \\
\text { days } 0,7,14,21 \text {, and } \\
28 . \text { Blood samples } \\
\text { were collected at } 24 \mathrm{~h} \\
\text { and } 29 \text { days. Tissue } \\
\text { samples were collected } \\
\text { at day } 29 \text {. }\end{array}$ & $\begin{array}{l}\text { Transferrin saturation } \\
\text { at end of study was } \\
\text { significantly higher } \\
\text { with all ISSs vs } \\
\text { Venofer and control. } \\
\text { All formulations had } \\
\text { significant tissue } \\
\text { deposition in liver, } \\
\text { heart, and kidney vs. } \\
\text { control. One } \\
\text { formulation of Venofer } \\
\text { showed highest values } \\
\text { for ferritin } \\
\text { immunostaining in the } \\
\text { liver. All ISS } \\
\text { formulations had } \\
\text { significantly higher IL- } \\
6 \text { immunostaining vs. } \\
\text { all three lots of } \\
\text { Venofer. }\end{array}$ \\
\hline Spicher et al & $\begin{array}{l}\text { Three approved IV iron } \\
\text { formulations (Venofer, } \\
\text { Ferrlecit, Ferinject) and } \\
\text { one ISS (FerMed, } \\
\text { Medice Arzneimittel }\end{array}$ & $\begin{array}{l}\text { ISS and Venofer }{ }^{\circledR} \text { were } \\
\text { administered at } 200 \\
\text { and } 400 \mu \text { into } \\
\text { chicken chorioallantoic }\end{array}$ & $\begin{array}{l}\text { No significant } \\
\text { difference in liver or } \\
\text { heart tissue deposition } \\
\text { was observed between } \\
\text { ISS and RLD. }\end{array}$ \\
\hline
\end{tabular}

This article is protected by copyright. All rights reserved. 


\begin{tabular}{|c|c|c|c|}
\hline & Pütter GmbH \& Co. KG) & membranes. & \\
\hline \multicolumn{4}{|l|}{ Humans } \\
\hline Rottembourg et al. & $\begin{array}{l}\text { Venofer and ISS } \\
\text { (Mylan SAS, Saint } \\
\text { Priest, France } \\
\text { manufactured by Help } \\
\text { SA Pharmaceuticals, } \\
\text { Athens, Greece) }\end{array}$ & $\begin{array}{l}\text { Retrospective study of } \\
\text { pre-post ISS switch in } \\
\text { hemodialysis patients } \\
(n=75) .\end{array}$ & $\begin{array}{l}\text { IV iron doses, ESA } \\
\text { doses and total drug } \\
\text { costs increased and } \\
\text { hemoglobin transiently } \\
\text { decreased post switch } \\
\text { to ISS. }\end{array}$ \\
\hline Lee $e t a l .^{24}$ & $\begin{array}{l}\text { RLD Venoferrum vs. } \\
\text { ISS Ferex } \\
\text { (SejongPharmas, South } \\
\text { Korea) }\end{array}$ & $\begin{array}{l}\text { Retrospective study of } \\
\text { postpartum patients } \\
\text { who received } \\
\text { Venoferrum ( } 200 \\
\mathrm{mg} / 100 \mathrm{~mL} \mathrm{NS}), \mathrm{ISS} \\
(200 \mathrm{mg} / 100 \mathrm{~mL} \mathrm{NS}) \text {, } \\
\text { and ISS ( } 200 \mathrm{mg} / 200 \\
\mathrm{~mL} \mathrm{NS}) . n=658\end{array}$ & $\begin{array}{l}\text { Adverse events } \\
\text { reported were } \\
\text { significantly lower with } \\
\text { Venoferrum. Injection- } \\
\text { site reactions and } \\
\text { phlebitis were } \\
\text { significantly higher in } \\
\text { ISS-treated patients, } \\
\text { especially with greater } \\
\text { dilution of ISS. }\end{array}$ \\
\hline Stein et al. & $\begin{array}{l}\text { ISS (FerMed, Medice } \\
\text { Arzneimittel Pütter } \\
\text { GmbH \& Co. KG) }\end{array}$ & $\begin{array}{l}\text { Case series of three } \\
\text { patients receiving ISS } \\
\text { who previously } \\
\text { tolerated Venofer }{ }^{\circledR} \\
(300 \mathrm{mg} / 300 \mathrm{~mL} \text { over } \\
1.5 \mathrm{~h}) .\end{array}$ & $\begin{array}{l}\text { All three patients } \\
\text { experienced adverse } \\
\text { drug reactions, } \\
\text { including urticaria, } \\
\text { headache, and } \\
\text { peripheral edema. }\end{array}$ \\
\hline Kuo et a & $\begin{array}{l}\text { ISS (Nan-Kuang } \\
\text { Pharmaceutical) vs. } \\
\text { control }\end{array}$ & $\begin{array}{l}\text { CKD stage } 5 \text { patients } \\
(n=40) \text { were randomly } \\
\text { allocated to receive ISS } \\
(100 \mathrm{mg} / 250 \mathrm{~mL}) \text { or } \\
\text { NS } 250 \mathrm{~mL} \\
\text { administered for } 60 \\
\text { min postdialysis for } 10 \\
\text { weeks. Blood samples } \\
\text { were collected every } 2 \\
\text { weeks. Healthy } \\
\text { subjects }(n=20) \text { had } \\
\text { blood collected once. }\end{array}$ & $\begin{array}{l}\text { CKD stage } 5 \text { subjects } \\
\text { receiving ISS had } \\
\text { highest ROS } \\
\text { production, soluble } \\
\text { adhesion molecule } \\
\text { concentrations (ICAM- } \\
\text { 1, VCAM-1), and ex } \\
\text { vivo monocyte-- } \\
\text { endothelial adhesion. }\end{array}$ \\
\hline Aguera $e t$ & $\begin{array}{l}\text { ISS and RLD } \\
\text { (manufacturers not } \\
\text { supplied) }\end{array}$ & $\begin{array}{l}\text { Prospective study after } \\
\text { institutional switch to } \\
\text { RLD from ISS ( } n= \\
342)\end{array}$ & $\begin{array}{l}\text { Reduced IV iron and } \\
\text { ESA doses required } \\
\text { during prospective } \\
\text { RLD observation } \\
\text { period. Hemoglobin } \\
\text { remained stable. }\end{array}$ \\
\hline
\end{tabular}

${ }^{a}$ Manufacturer not provided. ${ }^{b}$ Except $\operatorname{ISS}_{\mathrm{FERP}}\left(\right.$ Ferplex $\left.{ }^{\circledR}\right)$ in liver. VCAM-1, vascular cell adhesion molecule; ICAM-1, intracellular adhesion molecule; NF- $\mathrm{KB}$, nuclear factor $\kappa$ light-chain enhancer of activated B cells; IP, intraperitoneal; ROS, reactive oxygen species.

This article is protected by copyright. All rights reserved. 


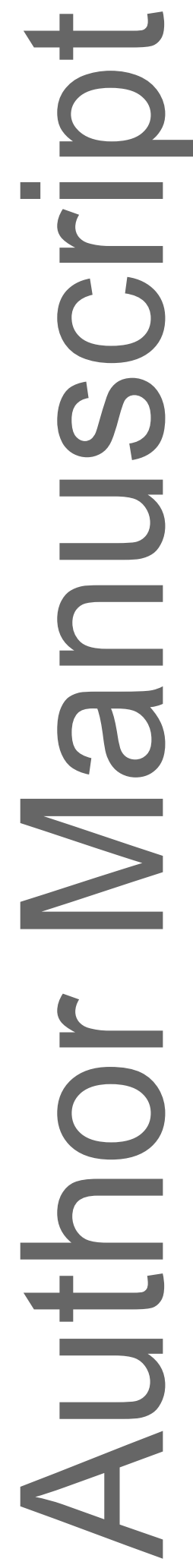

This article is protected by copyright. All rights reserved. 